\title{
Revision of the Australian Bee Genus Trichocolletes Cockerell (Hymenoptera: Colletidae: Paracolletini)
}

\author{
MiCHAEL BATLEY ${ }^{1 *}$ AND TERRY F. HOUSTON ${ }^{2}$ \\ ${ }^{1}$ Australian Museum, 6 College Street, Sydney NSW 2010, Australia \\ michael.batley@gmail.com \\ ${ }^{2}$ Western Australian Museum, Locked Bag 49, Welshpool D.C. WA 6986, Australia \\ Terry.Houston@museum.wa.gov.au
}

\begin{abstract}
The endemic Australian bee genus Trichocolletes is revised. Forty species are recognised, including twenty-three new species: Trichocolletes aeratus, T. albigenae, T. avialis, T. brachytomus, $T$. brunilabrum, T. capillosus, T. centralis, T. dundasensis, T. fuscus, T. gelasinus, T. grandis, T. lacaris, T. leucogenys, T. luteorufus, $T$. macrognathus, $T$. micans, $T$. nitens, $T$. orientalis, $T$. platyprosopis, $T$. serotinus, T. simus, T. soror and T. tuberatus. Four new synonymies are proposed: Paracolletes marginatus lucidus Cockerell, $1929=$ T. chrysostomus (Cockerell, 1929); . daviesiae Rayment, $1931=T$. venustus (Smith, 1862); T. marginatulus Michener, $1965=$ T. sericeus (Smith, 1862); T. nigroclypeatus Rayment, $1929=$ T. venustus (Smith, 1862). Trichocolletes rufus (Rayment, 1930) is moved to Leioproctus and $T$. rufopilosus (Rayment, 1935) to Anthoglossa. Descriptions are given for new species and redescriptions for species described before 1965, including first descriptions of males of T. aureotinctus (Cockerell), $T$. burnsi Michener, T. latifrons (Cockerell) and T. maximus (Cockerell) and the females of T. dowerinensis Rayment and T. rufibasis (Cockerell). Lectotypes are designated for Lamprocolletes venustus Smith and Anthoglossa plumata Smith. Keys to species are provided for both sexes, as are distribution maps and a summary of recorded floral visitation.
\end{abstract}

Batley, Michael, AND Terry F. Houston. 2012. Revision of the Australian bee genus Trichocolletes Cockerell (Hymenoptera: Colletidae: Paracolletini). Records of the Australian Museum 64(1): 1-50.

The monobasic genus Trichocolletes (Cockerell, 1912) was erected for the species Lamprocolletes venustus Smith by virtue of its conspicuously hairy eyes. Rayment $(1929,1931)$ added four additional species so that Cockerell's 1934 survey of the family Colletidae in Australia, listed five names in the genus Trichocolletes. When Michener (1965) revised the genera of Australian bees, he recognized that species without hairy eyes, previously placed in Anthoglossa and Paracolletes, belonged in a more broadly defined genus. At the same time Michener created a separate subgenus for the species $T$. pulcherrimus Michener, a decision he recently suggested (Michener, 2007) might merit reexamination. Since 1965, two new species have been added (Houston, 1990), but there has been no revision of the genus. This is, therefore, the first species-level revision of the genus Trichocolletes.

A recent molecular phylogeny of the family Colletidae (Almeida \& Danforth, 2009) concluded that the Australian and South American genera traditionally included in the tribe Paracolletini (Michener, 2007), excluding Callomelitta and Paracolletes s. str., form a monophyletic group and it has been proposed (Almeida et al., 2012) that the name Neopasiphaeinae should be used for this group. The phylogenetic analysis suggested that the genus Anthoglossa is sister to all other Neopasiphaeinae and the genus Trichocolletes is, in turn, sister to all Neopasiphaeinae other than Anthoglossa. Until morphological clarification of the status of Paracolletes is available, we have opted to follow Michener's (2007) family-level names. 